\title{
Egészségkommunikációs Felmérés Eredményei I. - Felnőtt felmérés
}

\author{
Results of the Health Communication Survey I. - Adult Survey
}

\author{
Szerzők: Balku Eszter $\bowtie$, Vitrai József \\ Nemzeti Egészségfejlesztési Intézet
}

Beküldve: 2016.06.10. Elfogadva: 2016.07.14.

\begin{abstract}
Összefoglaló: Bevezetés: A magyar lakosság egészségi állapota sokkal rosszabb annál, mint amiIyen a hasonló fejlettségű országokban tapasztaltak alapján elvárható lenne. Ennek egyik fő oka a Magyarországon gyakori egészségtelen életmód, azaz a helytelen táplálkozás, a mozgásszegény életmód, a dohányzás és a túlzott alkoholfogyasztás. Az Egészségkommunikációs Felmérés célja az volt, hogy feltérképezze az egészséggel kapcsolatos viselkedést és az ezeket meghatározó egészséggel kapcsolatos képességeket, motivációt és környezetet, valamint meghatározza a tervezett beavatkozásokhoz szükséges kommunikációs csatornákat. Módszerek: Az országos, kétlépcsős mintavétellel nyert reprezentatív mintán, kérdőíves felmérésben közel 5500 otthonában kérdezett felnőtt vett részt. A kérdőív a viselkedésváltoztatás egy integratív modelljére épült, amely szerint a viselkedést a testi és pszichés képességek, a motivációk valamint a társas és fizikai környezet által biztosított lehetőségek befolyásolják. A kérdések lefedték az egészséggel kapcsolatos ismereteket, attitűdöket, motivációkat, a testi, a lelki és a vélt egészséget, a pszichológiai tulajdonságokat, az egészségmagatartást, a társas támogatottságot, a kommunikációs szokásokat, az egészséggel kapcsolatos információkeresést valamint a kérdezett társadalmi-gazdasági jellemzőit. Eredmények: A felmérés leíró statisztikai elemzésének eredményeit a szerzők a viselkedésváltoztatási modellelemeknek megfelelő bontásban mutatják be. Az egészségmagatartásra vonatkozóan például kiderül, hogy minden 9. magyar felnőtt „szuper egészséges”, azaz elegendő zöldséget és gyümölcsöt fogyaszt, elegendő fizikai aktivitást végez, nem dohányozik, legfeljebb mérsékelten fogyaszt alkoholt és testtömege normális tartományban van. Összegzés: Az eredmények alátámasztják, hogy az egészségmagatartás megváltoztatásához nem elegendő az ismeretátadás, egyaránt fontos a motiváció és a támogató környezet is. A magyar felnőttek fizikai-pszichikai képességeire, motivációira, társas illetve fizikai környezetére és viselkedésére vonatkozó leíró eredmények hasznosak lehetnek az egészségfejlesztés különböző területein tevékenykedő szakemberek számára.
\end{abstract}

Kulcsszavak: felmérés, egészségkommunikáció, egészség, testmozgás, médiafogyasztás

Summary: Background: The health of the Hungarian population is much poorer than expected compared to that of countries with a similar level of development. One if its main reasons is unhealthy lifestyle, that is, unhealthy nutrition, low level of physical activity, smoking and alcohol abuse. The aim of the Health Communication Survey was to map health related behavior and health related skills, motivation and environment, as its determinants, and to identify communication channels to be used in the planned interventions. Methods: Nationally representative twostage samples of adults were drawn and about 5500 respondents were questioned at home. The questionnaire was built on an integrative model of behavioral change, which states that health behavior is determined by physical and psychical capabilities, motivations, and opportunities provided by physical and social environment. The questions cover knowledge about and attitude to 
health, somatic and mental health status, subjective well-being, psychological characteristics, health behaviors, social support, media consumption, health-related information seeking, and socio-demographic characteristics. Results: Results of the descriptive statistical analysis are presented in blocks according to the elements of the behavior change model used. For health behavior it turns out that every 9th Hungarian adult is "super healthy" since eats sufficient amount vegetables and fruit, is physically active enough, doesn't smoke and drink too much alcohol, and has body mass index in normal range. Summary: These results, relating to the physical-mental skills, motivation, social and physical environment of the Hungarian population might be useful for professionals working in the different fields of health promotion.

Keywords: survey, health communication, health, physical activity, media consumption

\section{BEVEZETÉS}

Magyarországon a lakosság egészségi állapota roszszabb, mint ami az ország fejlettsége alapján elvárható lenne. ${ }^{1}$ Ennek oka lehet többek között a helytelen táplálkozás, a mozgásszegény életmód, a túlzott alkoholfogyasztás, a dohányzás és általában az egészségtudatosság alacsony szintje. Az Egészségkommunikációs Felmérés (EKF) célja az volt, hogy feltérképezze ezeknek a kockázati magatartásoknak a hátterét oly módon, hogy felméri a magyar lakosok egészséggel kapcsolatos ismereteit, attitűdjét és a viselkedését befolyásoló környezetet, továbbá a felmérés eredményei által tervezett új megközelítésű beavatkozásokhoz meghatározza a megfelelő kommunikációs csatornákat. A közlemény bemutatja a felnőtt EKF leíró statisztikai elemzésének eredményeit.

\section{MÓDSZERTAN}

A felmérés tervezése során olyan elméleti alapra, modellre volt szükség, amely jól leírja a magatartásváltoztatás elméletét. Ilyen elméletek tucatjai születtek az elmúlt évtizedekben, ${ }^{2}$ amelyek áttekintésére, öszszegzésére az elméleti és alkalmazott pszichológia neves szakembereinek egy csoportja vállalkozott a 2000-es évek elején. ${ }^{3}$ Az áttekintett elméletek integrálásával Michie és munkatársai megalkották az un. COM-Bi modellt, amely leírja az egészségmagatartás és az azt befolyásoló tényezők összetett hatásrendszerét. ${ }^{4,5} \mathrm{~A}$ kitűzött célok eléréséhez az EKF ezt a modellt vette alapul, és használta fel a kérdőív kialakítása során. ii A 19 pszichológiai elméletet összegző, szakmai konszenzus alapján kidolgozott COM-B modell szerint a viselkedést először is a "Képesség”, azaz az egyénnek vagy a közösségnek a viselkedés megvalósításhoz szükséges testi és lelki készségei szabják meg. ${ }^{6}$ A "Motivációt" a cselekvést elindító tudatos döntések, szándékok és automatikusan adott válaszok, szokások alkotják. A cselekvés megvalósulását a „Körülmények”, azaz a fizikai valamint a szociális-kulturális környezet is nagymértékben meghatározza. Megjegyzendő, hogy a modell szerint a viselkedés visszahat a három befolyásoló tényezőre, és azok egymásra is hatással vannak. [1. ábra]

1. ábra: COM-B modell: a viselkedés és azt befolyásoló tényezők rendszere

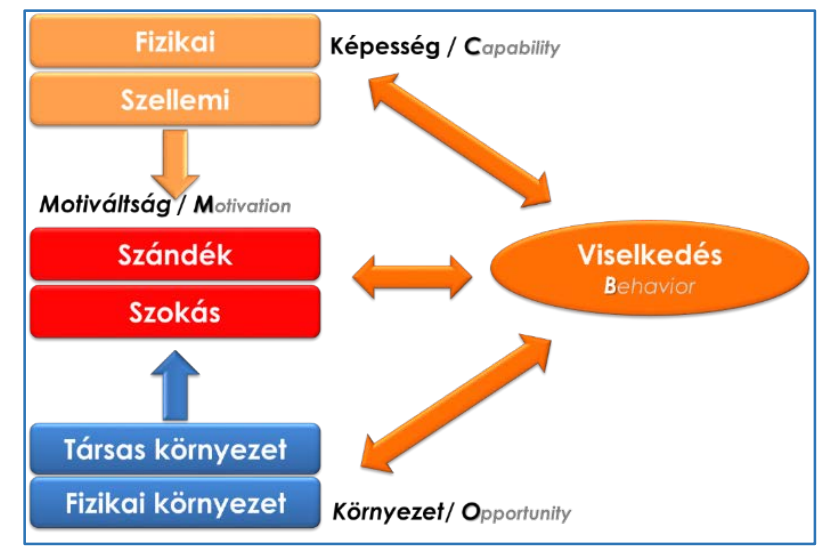

Forrás: Balku E, Berki J, Csizmadia P, et al (2015) Health Riport. National Institute for Health Development

A COM-B modell nem csak a felmérés elméleti hátte-

\footnotetext{
'A mozaikszó az angol Capability, Opportunity, Motivation és a Behaviour kifejezések kezdőbetűiből származik

ii A kérdőív a közlemény mellékletében elérhető
} 
rét és céljait határozza meg, hanem a felmérésben használt kérdőív témakörei is a modell alapján az 1. táblázatban található módon kerültek meghatározásra és kidolgozásra.

A felmérés 10 ezer fős mintája kétlépcsős mintavételi eljárással készült, a felmérés adatainak súlyozása a teljes populációs sokasági jellemzőkre nézve került kialakításra, illetőleg az adatok belső homogenitását fi- gyelembe vevő, a design hatást korrigálandó másodlagos súlyozás is készült, ahol a súlyok iteratív eljárást alkalmazva kerültek meghatározásra. Az eredmények bemutatása több bontási szempontból is indokolt lehet, azonban az egyszerúség elvét követve, a közleményben csak a teljes lakosságra vannak bemutatva az eredmények és csak egyes, érdekesnek vélt eredmény esetében kerül sor további bontásokra. ${ }^{\text {iii }}$

1. táblázat: A felmérés kérdőivének témakörei és a témakörökhöz tartozó kérdések száma

\begin{tabular}{|c|c|c|}
\hline COM-B elemei & Témakörök & Kérdések száma \\
\hline \multirow{3}{*}{ 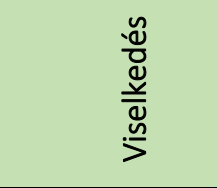 } & Egészségmagatartás $7,8,9,10,11,12$ & 19 \\
\hline & Médiafogyasztás ${ }^{13,14}$ & 6 \\
\hline & Egészséginformáció keresés ${ }^{15}$ & 10 \\
\hline \multirow{6}{*}{ 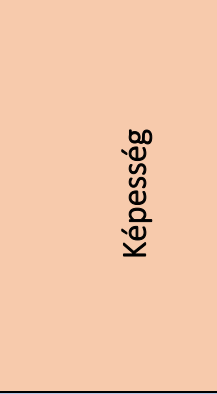 } & Egyéni jellemző́k & 10 \\
\hline & Egészségi állapot ${ }^{16,17}$ & 16 \\
\hline & Hiedelem ${ }^{18}$ & 16 \\
\hline & Viszony a változáshoz ${ }^{19}$ & 12 \\
\hline & Énhatékonyság ${ }^{20}$ & 7 \\
\hline & Személyiségvonás ${ }^{21}$ & 15 \\
\hline \multirow{9}{*}{ 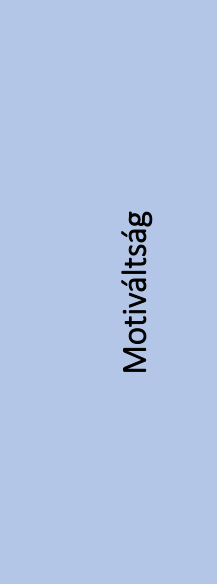 } & Változtatási szándék & 5 \\
\hline & Testkép ${ }^{22}$ & 1 \\
\hline & Egészséghez való viszony ${ }^{23}$ & 12 \\
\hline & Egészségmagatartáshoz való viszony $y^{24,25,26}$ & 10 \\
\hline & Akadályozottság & 8 \\
\hline & Élettel való elégedettség ${ }^{27}$ & 1 \\
\hline & Életcél ${ }^{28}$ & 9 \\
\hline & Élménykeresés ${ }^{16,29}$ & 10 \\
\hline & Választott hipotetikus egészséginformáció-forrás ${ }^{28}$ & 10 \\
\hline \multirow{4}{*}{ 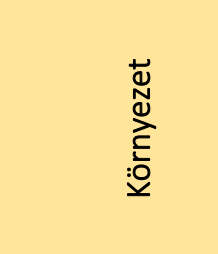 } & Háztartási jellemzőḱk ${ }^{16,30}$ & 5 \\
\hline & Elvárás & 6 \\
\hline & Kifogás egészségmagatartás-változtatással szemben & 3 \\
\hline & Társas támogatottság & 3 \\
\hline & Összesen: & 194 \\
\hline
\end{tabular}

iii A felmérés illetve az adatelemzés módszertanát részletesebben ismertetető kézirat a Journal of Public Health folyóirathoz került benyújtásra 2016.06.15.-én 


\section{EREDMÉNYEK}

A 2015 tavaszán végzett felmérés során 5498 fővel készült elemzésre használható kérdőívfelvétel (vá- laszarány: 55\%). A minta és a magyar felnőtt lakosság életkori csoportok és nem szerinti összehasonlítását a 2. táblázat, a lakóhely régió és nem szerinti összehasonlítását a 3. táblázat mutatja be.

2. táblázat: A felmérés megvalósult mintájának valamint a magyar népesség korcsoportos és nem szerinti megoszlása

\begin{tabular}{|c|c|c|c|c|c|c|c|c|c|c|c|c|}
\hline \multirow{3}{*}{$\begin{array}{l}\text { Korcsoport (év) } \\
18-24\end{array}$} & \multicolumn{6}{|c|}{ MINTA } & \multicolumn{6}{|c|}{ MAGYAR NÉPESSÉG 2011 (KSH) } \\
\hline & \multicolumn{2}{|c|}{ Nök } & \multicolumn{2}{|c|}{ Férfiak } & \multicolumn{2}{|c|}{ Együtt } & \multicolumn{2}{|l|}{ Nök } & \multicolumn{2}{|c|}{ Férfiak } & \multicolumn{2}{|c|}{ Együtt } \\
\hline & 273 & $5 \%$ & 276 & $5 \%$ & 549 & $10 \%$ & 421334 & $5 \%$ & 443131 & $5 \%$ & 864465 & $11 \%$ \\
\hline $25-34$ & 408 & $7 \%$ & 374 & $7 \%$ & 782 & $14 \%$ & 680477 & $8 \%$ & 696141 & $9 \%$ & 1376618 & $17 \%$ \\
\hline $35-44$ & 527 & $10 \%$ & 492 & $9 \%$ & 1019 & $19 \%$ & 759571 & $9 \%$ & 770546 & $9 \%$ & 1530117 & $19 \%$ \\
\hline $45-54$ & 422 & $8 \%$ & 421 & $8 \%$ & 843 & $15 \%$ & 646865 & $8 \%$ & 612378 & $8 \%$ & 1259243 & $15 \%$ \\
\hline $55-64$ & 535 & $10 \%$ & 460 & $8 \%$ & 995 & $18 \%$ & 777603 & $10 \%$ & 657499 & $8 \%$ & 1435102 & $18 \%$ \\
\hline $65-74$ & 447 & $8 \%$ & 309 & $6 \%$ & 756 & $14 \%$ & 562001 & $7 \%$ & 384814 & $5 \%$ & 946815 & $12 \%$ \\
\hline $75+$ & 381 & $7 \%$ & 173 & $3 \%$ & 554 & $10 \%$ & 497563 & $6 \%$ & 232742 & $3 \%$ & 730305 & $9 \%$ \\
\hline Együtt & 2993 & $54 \%$ & 2505 & $46 \%$ & 5498 & $100 \%$ & 4345414 & $53 \%$ & 3797251 & $47 \%$ & 8142665 & $100 \%$ \\
\hline
\end{tabular}

3. táblázat: A felmérés megvalósult mintájának valamint a magyar népesség lakóhely régiója és nem szerinti megoszlása

\begin{tabular}{|c|c|c|c|c|c|c|c|c|c|c|c|c|}
\hline \multirow{3}{*}{$\begin{array}{l}\text { Régió } \\
\text { Dél-Alföld }\end{array}$} & \multicolumn{6}{|c|}{ MINTA } & \multicolumn{6}{|c|}{ MAGYAR NÉPESSÉG 2011 (KSH) } \\
\hline & \multicolumn{2}{|c|}{ Nök } & \multicolumn{2}{|c|}{ Férfiak } & \multicolumn{2}{|c|}{ Együtt } & \multicolumn{2}{|l|}{ Nök } & \multicolumn{2}{|c|}{ Férfiak } & \multicolumn{2}{|c|}{ Együtt } \\
\hline & 405 & $7 \%$ & 346 & $6 \%$ & 751 & $14 \%$ & 568248 & $7 \%$ & 498497 & $6 \%$ & 1066745 & $13 \%$ \\
\hline Dél-Dunántúl & 280 & $5 \%$ & 231 & $4 \%$ & 511 & $9 \%$ & 410477 & $5 \%$ & 357233 & $4 \%$ & 767710 & $9 \%$ \\
\hline Észak-Alföld & 464 & $8 \%$ & 409 & $7 \%$ & 873 & $16 \%$ & 631648 & $8 \%$ & 560070 & $7 \%$ & 1191718 & $15 \%$ \\
\hline $\begin{array}{l}\text { Észak- Ma- } \\
\text { gyarország }\end{array}$ & 359 & $7 \%$ & 298 & $5 \%$ & 657 & $12 \%$ & 515262 & $6 \%$ & 449274 & $6 \%$ & 964536 & $12 \%$ \\
\hline $\begin{array}{l}\text { Közép-Dunán- } \\
\text { túl }\end{array}$ & 329 & $6 \%$ & 284 & $5 \%$ & 613 & $11 \%$ & 465750 & $6 \%$ & 423929 & $5 \%$ & 889679 & $11 \%$ \\
\hline $\begin{array}{l}\text { Közép-Ma- } \\
\text { gyarország }\end{array}$ & 854 & $16 \%$ & 648 & $12 \%$ & 1502 & $27 \%$ & 1324788 & $16 \%$ & 1120537 & $14 \%$ & 2445325 & $30 \%$ \\
\hline $\begin{array}{l}\text { Nyugat-Du- } \\
\text { nántúl }\end{array}$ & 302 & $5 \%$ & 289 & $5 \%$ & 591 & $11 \%$ & 429241 & $5 \%$ & 387711 & $5 \%$ & 816952 & $10 \%$ \\
\hline Együtt & 2993 & $54 \%$ & 2505 & $46 \%$ & 5498 & $100 \%$ & 4345414 & $53 \%$ & 3797251 & $47 \%$ & 8142665 & $100 \%$ \\
\hline
\end{tabular}

A táblázatok alapján megállapítható, hogy az alacsony válaszarány ellenére a megvalósult minta nem tér el jelentősen a népszámláláskor rögzített adatok alapján számított megoszlásoktól. A súlyozással kiigazított adatok elemzésével nyert eredmények a teljes magyar felnőtt lakosságra reprezentatívnak tekinthetők.

Elsőként a fizikai aktivitásra vonatkozó eredményekkel célszerü demonstrálni, hogy miért fontos a COM-B modell alkalmazása a viselkedés változtatását célzó beavatkozások tervezésekor. A magyar felnőttek 97\%-a tudja, hogy mennyire fontos a testmozgás (képesség), azonban csak 27\%-uk végez rendszeres testmozgást (viselkedés). A motivációt vizsgálva megállapítható, hogy a felnőttek $21 \%$-a tervezi a rendszeres testmozgás elkezdését a közeljövőben, de csak kevesebb, mint fele (43\%) gondolja úgy, hogyha újévkor megfogadná, hogy hetente háromszor fog mozogni, akkor biztosan be is tudná tartani. A rendszeres fizikai aktivitás alacsony szintjének egyik magyarázata lehet az, hogy csak minden harmadik felnőtt környezete támogatja ezt a magatartást. [2. ábra] Ez a példa is rávilágít, hogy az egészségmagatartás megváltoztatásához nem elegendő az ismeretátadás, egyaránt fontos a motiváció és a támogató környezet is. 
2. ábra: A nem megfelelö fizikai aktivitás viselkedés, valamint a COM-B modell szerinti viselkedést befolyásoló tényezők megoszlása a felnőtt lakosságban

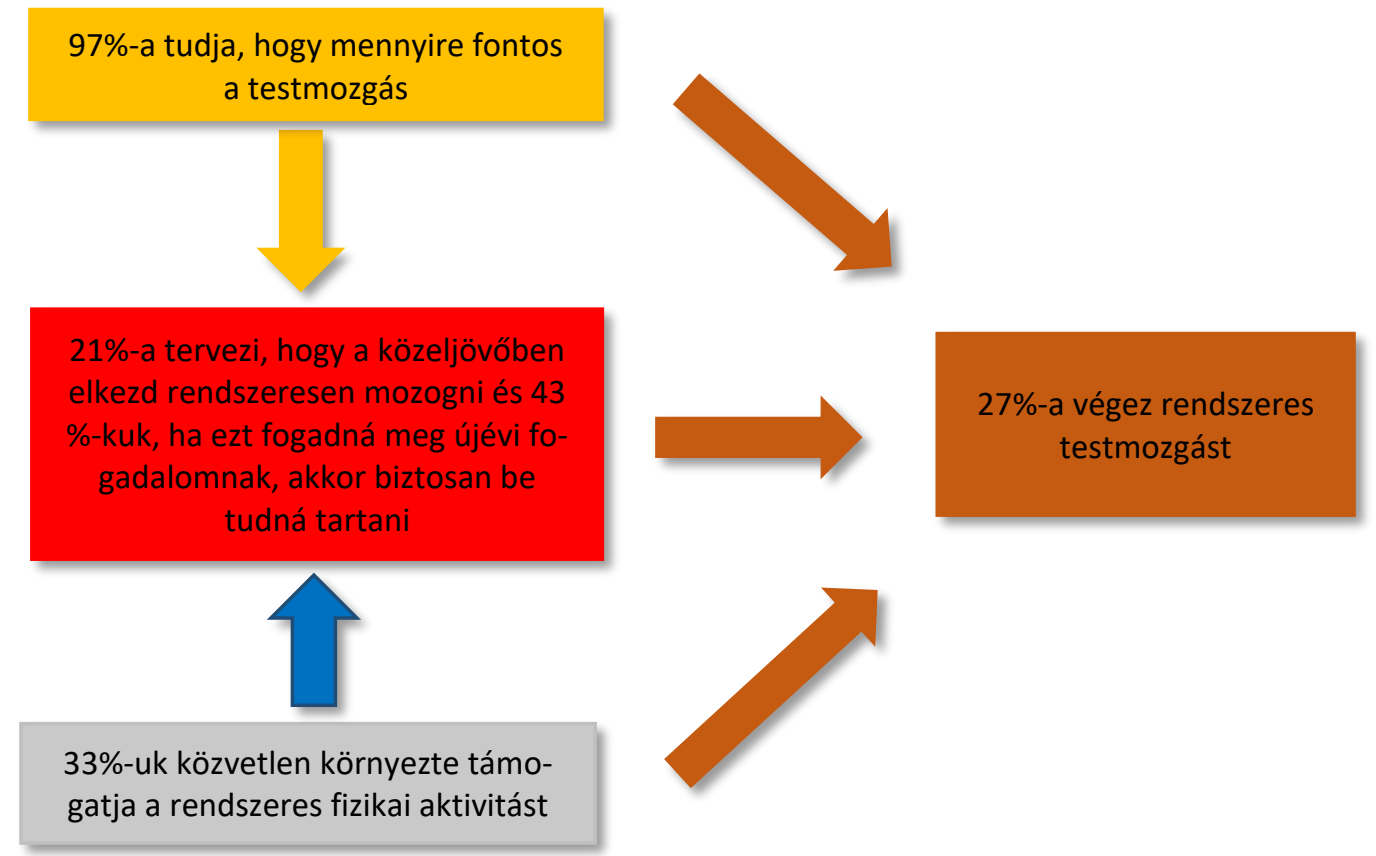

A felmérés további eredményei az elméleti modell 4 eleme szerint, tagolva kerülnek bemutatásra.

\section{VISELKEDÉS}

A felnőtt magyar lakosság 11\%-a tekinthető „szuper egészségesnek", azaz elegendő zöldséget és gyümölcsöt fogyaszt, elegendő fizikai aktivitást végez, nem dohányzik, egyáltalán nem, vagy mérsékelten fogyaszt alkoholt és a testtömegindexe ${ }^{i v}$ (TTI) szerint normális a testsúlya. Azokat tekintjük „szuper egészségtelenek", akik nem fogyasztanak elegendő a zöldséget és gyümölcsöt, fizikailag inaktívak, dohányoznak, és túlzott mértékben fogyasztanak alkoholt, illetve a TTI alapján túlsúlyosak vagy elhízottak. Ebbe a csoportba a magyar lakosok csupán 0,3\%-a tartozik.

Az egészséges táplálkozás jellemzésére a zöldség-és gyümölcsfogyasztást választottuk indikátornak, és az eredmények alapján a magyar felnőttek kicsivel több, mint fele (56\%) fogyaszt napi rendszerességgel zöldséget és/vagy gyümölcsöt.

Az egészséges életmód elengedhetetlen eleme a rendszeres fizikai aktivitás, emiatt fontos elemezni részletesebben a magyar felnőttek testmozgását.
Az eredmények azt mutatják, hogy a felnőttek 41\%a soha nem végez testmozgást szabadidejében, 55\%-uk még 10 percet sem kerékpározik egy héten, 31\%-uk kevesebb, mint napi húsz percet sétál és 73\%-uk nem végez rendszeres testedzést, vagyis nem jár aerobicra, nem kocog vagy úszik.

A dohányzásra és alkoholfogyasztásra vonatkozó válaszok alapján megállapítható, hogy a felnőtt lakosság 31\%-a használ valamilyen rendszerességgel dohányterméket, a lakosok fele soha nem fogyaszt alkoholt, kicsivel több, mint 5\%-a pedig a nagyivók közé tartozik. ${ }^{v}$

Az orvoshoz fordulás mind a megelőzés, mind a gyógyulás szempontjából kiemelten fontos és vizsgálandó egészségmagatartás. Az előző egy évben a magyar felnőttek 71\%-a találkozott a háziorvosával, 48\%-a szakorvossal és csak 18\%-a találkozott más egészségügyi szolgáltatást nyújtó szakemberrel.

A médiafogyasztási szokások vizsgálata alapján a televízió a legnépszerúbb médium, második a rádió és csak a harmadik az internet. [4. táblázat]

\footnotetext{
iv A TTI a kg-ban megadott testtömeg osztva a testmagasság méterben kifejezett értékének négyzetével.

` Nagyivónak neveztük azokat a nőket, akik a kérdezést megelőző héten összesen több mint 7, illetve azokat a férfiakat, akik több mint 14 egységnyi alkoholt fogyasztottak, valamint azokat, akik egy alkalommal 6 vagy több italt fogyasztanak. Egy ital/alkoholegység egy korsó sörnek, 2 dl bornak vagy 0,5 dl röviditalnak felel meg, azaz 1 dl sör 0,2 italnak, 1 dl bor 0,5 italnak és 0,1 dl rövidital 0,2 italnak számít.
} 
4. táblázat: Médiafogyasztási szokások megoszlása

\begin{tabular}{|c|c|}
\hline Médiumok & Néz, hallgat, használ, olvas (\%) \\
\hline TV & 94,3 \\
\hline Rádió & 61,7 \\
\hline Internet & 58,9 \\
\hline Újság & 56,2 \\
\hline
\end{tabular}

Korcsoportonként vizsgálva kiderül, hogy a fiatalok (18-35 évesek) körében az internet az első helyre kerül és a tv nézés gyakoriságával egyenlő (91-91\%). Az idősebbek a fiataloknál jóval kisebb arányban használják az internetet, a 36-65 évesek 63\%-a, a 65 év felettiek csupán 11\%-a. A rendszeres internethasználók leggyakrabban a közösségi oldalakat látogatják, de nem osztanak meg tartalmakat (passzívak), és a hírportálokat, on-line újságokat olvassák a legszívesebben. [5. táblázat]

A magyar felnőtt lakosság az egészséggel összefüggő információk közül a betegséggel kapcsolatos témákban keres aktívan, mint például, hogy hová le-
5. táblázat: Internet használok internetes tevékenységeinek megoszlása

\begin{tabular}{|l|c|}
\hline \multicolumn{1}{|c}{ Internetes tevékenységek } & $\begin{array}{c}\text { Azok aránya, akik } \\
\text { végzik (\%) }\end{array}$ \\
\hline $\begin{array}{l}\text { Közösségi oldalak látogatása (pasz- } \\
\text { szív) }\end{array}$ & 87,6 \\
\hline $\begin{array}{l}\text { Közösségi oldalak látogatása (aktív) } \\
\begin{array}{l}\text { Hírportálok, on-line újságok, blogok } \\
\text { olvasása }\end{array}\end{array}$ & 72,5 \\
\hline \begin{tabular}{l} 
Szakmai oldalak olvasása \\
\hline
\end{tabular} & 67,8 \\
\hline
\end{tabular}

het fordulni egy egészségproblémával, de még így is csak kevesebb, mint a lakosok fele keres információt ebben a témakörben. A legtöbb témában a szakembereket jelölték meg elsődleges hipotetikus információforrásként (vagyis akit megkeresnének, ha kérdésük merülne fel), kivéve az életvezetés és családi élet témáját, mert e téren a családtagot jelölték meg legkompetensebb személynek. [6. táblázat] A keresett témák sorrendje és az elsődlegesen megjelölt források korcsoportonként változnak; például a fiatalok a testápolás és az alternatív gyógyászat témában már az internetet jelölik meg elsődleges forrásnak.

6. táblázat: Egyes egészséggel kapcsolatos témákban információt keresők aránya és az ahhoz elsődlegesen megjelölt információforrás

\begin{tabular}{|c|c|c|}
\hline Témakörök & $\begin{array}{c}\text { Az adott témában infor- } \\
\text { mációt kereső́k aránya vi } \\
(\%)\end{array}$ & $\begin{array}{c}\text { Elsődlegesen megjelölt hi- } \\
\text { potetikus információfor- } \\
\text { rás }\end{array}$ \\
\hline betegséggel kapcsolatban hova lehet fordulni & 39,2 & szakember \\
\hline egészségi problémák, betegségek & 38,7 & szakember \\
\hline egészségügyi szűrések & 33,6 & szakember \\
\hline testápolás, a fog, bőr, haj, és köröm egészségével kapcsolatos kérdések & 27,9 & szakember \\
\hline életvezetés és családi élet, emberi kapcsolatok & 22,8 & családtag \\
\hline védőoltások & 22 & szakember \\
\hline $\begin{array}{l}\text { lelki egészség problémái, mint például, stressz, depresszió vagy alvás- } \\
\text { probléma }\end{array}$ & 21,8 & szakember \\
\hline $\begin{array}{l}\text { alternatív gyógyászat és egészségmegőrzés, mint például, homeopátia, } \\
\text { akupunktúra, léböjt-kúra }\end{array}$ & 21,3 & szakember \\
\hline $\begin{array}{l}\text { egészségtelen szokások, mint például, dohányzás, kevés testmozgás, } \\
\text { túlzott alkoholfogyasztás }\end{array}$ & 16,3 & szakember \\
\hline gyerekvállalás, várandósság, gyereknevelés, a gyerekek egészsége & 15,1 & szakember \\
\hline
\end{tabular}

\footnotetext{
${ }^{v i}$ Az adott témakörben való információkeresést a válaszolók 1-től 5-ig tartó skálán jelölhették magukra vonatkozóan jellemzőnek. Információkeresőnek számítottak azok, akik a skálán 4-est vagy 5-öst választottak.
} 


\section{KÉPESSÉG}

A magyar lakosok 51\%-a véli jónak vagy nagyon jónak egészségi állapotát. 36\%-uknak van valamilyen hosszan tartó betegsége vagy egészségügyi problémája, amely 8\%-ukat súlyosan korlátozza a mindennapi tevékenységekben.

A depresszió meghatározásra használt Patient Health Questionnaire $(P H Q)^{31}$ kérdőív kérdései alapján kidolgozott 12 állítást a válaszadók 1-től 5-ig érté- kelték magukra jellemzőként úgy, hogy a magasabb érték a depresszió nagyobb mértékére utalt. ${ }^{\text {vii }}[7$. táblázat] A 12 állításra adott válaszok összege így minimálisan 12, azaz egyik állítás sem jellemző a válaszolóra, a maximum pedig 60 , ami azt jelenti, hogy minden állítás teljes mértékben igaz a válaszolóra. A minimális 12 pont a felnőttek 28\%-ára, a maximális 60 pont a teljes felnőtt lakosság 0,3\%-ára volt jellemző. A magyar lakosok fele 18 vagy annál kevesebb pontot ért el és az átlag pontszám 21,4 volt. [3. ábra]

7. táblázat: A depresszió mérésére alkalmazott PHQ kérdésekre adott válaszok átlaga

\begin{tabular}{|l|c|}
\hline \multicolumn{1}{|c|}{ Depresszió mérésére vonatkozó állítások } & Válaszok átlaga \\
\hline Egész nap fáradtnak érezte magát. & 2,2 \\
\hline Gondjai voltak az alvással. & 2,0 \\
\hline Úgy érezte, hogy nem érdekes, amit csinál. & 1,9 \\
\hline Úgy érezte, nem okoz örömet, amit csinál. & 1,9 \\
\hline Alig tudott figyelni arra, amit csinált. & 1,8 \\
\hline Szomorú volt, depressziósnak érezte magát. & 1,8 \\
\hline Túlzottan nyugtalannak érezte magát. & 1,8 \\
\hline Túlságosan nyugodt, lelassult volt. & 1,7 \\
\hline Gondjai voltak az étvágyával. & 1,6 \\
\hline Úgy érezte, csalódást okozott családjának. & 1,6 \\
\hline Úgy érezte, csalódást okozott önmagának. & 1,6 \\
\hline Arra gondolt, hogy legjobb lenne meghalni. & 1,4 \\
\hline
\end{tabular}

3. ábra: A PHQ skálával mért depresszió mértékének alakulás a magyar felnőtt lakosok körében

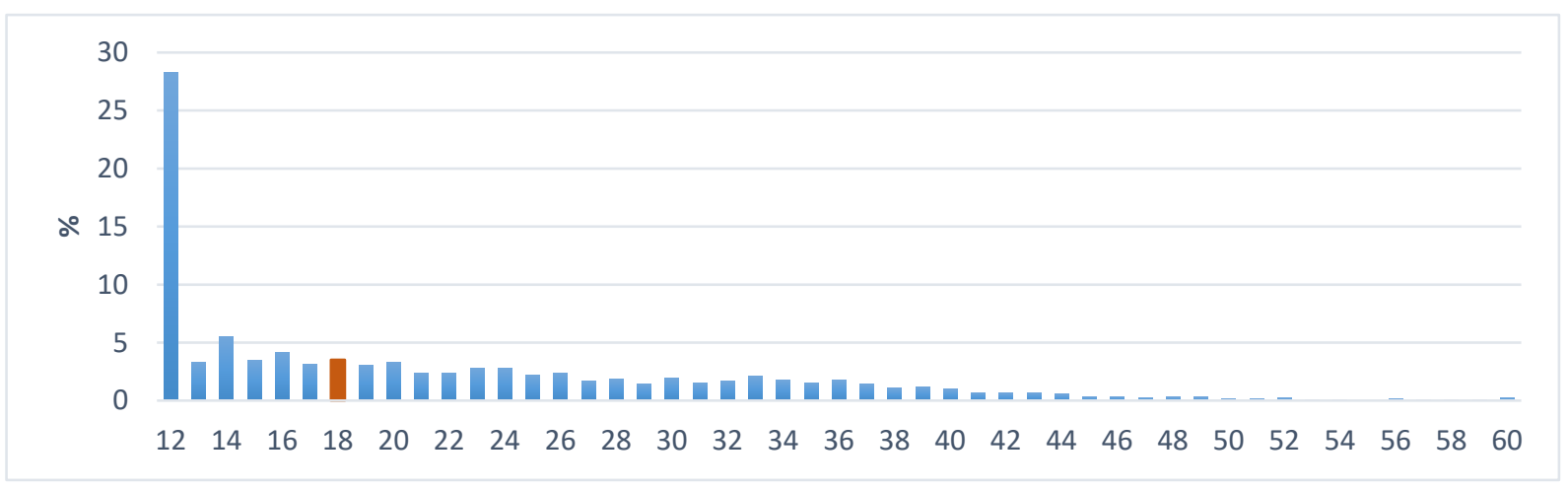

\footnotetext{
vii A PHQ kérdőívnek az eredetihez képest módosított formában való használata miatt a válaszok csak a megszokottól eltérően értékelhetők.
} 
A testi képességek kiemelten fontos jellemzője a tápláltsági állapot, aminek mérésére általában a TTI mutatót használják. A testtömegindex alapján a felnőtt lakosság 61\%-a túlsúlyosnak vagy elhízottnak számít. Közülük csak 45\%-uk véli azt, hogy a kelleténél nagyobb a testsúlya, és testalkatát is túlsúlyosként jellemzi.

Az egészséggel kapcsolatos ismeretek a pszichés képességek meghatározó részét alkotják. A 8. táblázat arról tájékoztat, hogy miként oszlanak meg az egészséggel kapcsolatos ismeretek a magyar felnőttek körében. A testmozgás jótékony hatása a lakosok $80 \%$-a által ismert, és közel 70\%-uk úgy véli, az nemcsak az elhízás ellen hatásos. A gyógyszerszedésre vonatkozó ismeretek a felnőttek kétharmadánál hiányosak, mert 60\%-uk úgy gondolja, hogy a receptre felírt orvosságot addig kell szedni, amíg a panaszok el nem múlnak.

8. táblázat: Egészséggel kapcsolatos állitásokkal egyetértők aránya és a válaszok átlaga

\begin{tabular}{|c|c|c|}
\hline Egészséggel kapcsolatos állítás & $\begin{array}{c}\text { Az adott állítással } \\
\text { egyet értő́k vagy teljes } \\
\text { mértékben egyet ér- } \\
\text { tők arányaviii } \\
(\%)\end{array}$ & Válaszok átlaga \\
\hline A terhesség alatti dohányzás árt a magzatnak. & 90,5 & 4,5 \\
\hline Mások dohányfüstjének beszívása is káros egészségünkre. & 88,6 & 4,4 \\
\hline $\begin{array}{l}\text { A dohányzást azért is nehéz abbahagyni, mert a dohányos szervezete hozzászo- } \\
\text { kott a nikotinhoz, és folyamatosan kívánja. }\end{array}$ & 81,7 & 4,2 \\
\hline $\begin{array}{l}\text { Aki sok zöldséget, gyümölcsöt eszik, annak ellenállóbb a szervezete a betegsé- } \\
\text { gekkel szemben. }\end{array}$ & 81,2 & 4,3 \\
\hline $\begin{array}{l}\text { A testmozgás csökkentheti a krónikus betegségek (pl. cukorbetegség) kialakulá- } \\
\text { sának esélyét. }\end{array}$ & 80,0 & 4,2 \\
\hline $\begin{array}{l}\text { A testmozgás a krónikus betegségekben (pl. egyes szívbetegségekben, magas } \\
\text { vérnyomásban) szenvedők számára jótékony hatású. }\end{array}$ & 80,0 & 4,2 \\
\hline $\begin{array}{l}\text { Sok mozgásra azért van szükség, hogy az ember ne hízzon el, vagy, hogy lefogy- } \\
\text { jon. }\end{array}$ & 68,4 & 3,9 \\
\hline Sok idő és sok pénz kell az egészséges ételek elkészítéséhez. & 62,5 & 3,8 \\
\hline Receptre felírt orvosságot addig kell szedni, amíg a panaszok el nem múlnak. & 60,2 & 3,6 \\
\hline $\begin{array}{l}\text { Amikor valaki energiaitalt és alkoholt együtt fogyaszt, nehezen veszi észre, ha a } \\
\text { kelleténél többet ivott. }\end{array}$ & 58,9 & 3,7 \\
\hline A dohányzó szülő gyereke nagyobb eséllyel fog dohányozni. & 52,5 & 3,5 \\
\hline $\begin{array}{l}\text { Igazából nem lehet tudni, melyik étel egészséges, mert a szakértők sem érte- } \\
\text { nek egyet. }\end{array}$ & 50,6 & 3,4 \\
\hline Az elektronikus cigaretta (e-cigi) ártalmatlan az egészségre. & 41,2 & 3,1 \\
\hline $\begin{array}{l}\text { A terhesség alatt alkalmanként fogyasztott alkohol (pl. } 1 \text { pohár bor) nem árt a } \\
\text { magzatnak. }\end{array}$ & 35,0 & 2,9 \\
\hline Az elfogyasztott alkohol átmelegít, véd a kihúlés, a megfagyás ellen. & 26,5 & 2,7 \\
\hline $\begin{array}{l}\text { Csak a szülőktől örökölt tulajdonságokon múlik, hogy milyen betegségünk lesz } \\
\text { életünk során. }\end{array}$ & 22,5 & 2,7 \\
\hline
\end{tabular}

\footnotetext{
viii Az adott, egészséggel kapcsolatos állitással való egyetértés erősségét a válaszolók 1-től 5-ig tartó skálán jelölhették. Egyetértőnek számítottak azok, akik a skálán 4-est vagy 5-öst választottak.
} 
A kitartás, az eltökéltség a pszichés képességek fontos elemei. A magyar felnőttek szerint, ha elhatároznák, hogy megváltoztatják viselkedésüket, a 9. táblázatban található sorrendben tudnák betartani a viselkedésváltozásra vonatkozó újévi fogadalmakat.
Legtöbben a szakemberhez való fordulással kapcsolatos fogadalmat tudnák betartani, legkevesebben pedig a rendszeres testmozgásra vonatkozó fogadalmat.

9. táblázat: Az egészséggel kapcsolatos fogadalmak vélt betartásának megoszlása és a válaszok átlaga

\begin{tabular}{|c|c|c|}
\hline Egészséggel kapcsolatos fogadalmak & $\begin{array}{c}\text { Azon lakosok aránya, akik, ha meg- } \\
\text { fogadnák, biztosan betartanák az } \\
\text { adott fogadalmatix } \\
(\%)\end{array}$ & Válaszok átlaga \\
\hline $\begin{array}{l}\text { Szakemberhez fordulni, ha egészségével kapcsolatban vala- } \\
\text { milyen probléma merül fel }\end{array}$ & 74,3 & 3,9 \\
\hline Egészségesebben táplálkozni & 57,9 & 3,5 \\
\hline $\begin{array}{l}\text { Több időt biztosítani kikapcsolódásra, lazításra, feltöltő- } \\
\text { désre }\end{array}$ & 55,6 & 3,4 \\
\hline Abbahagyni az alkoholfogyasztást & 54,8 & 2,9 \\
\hline Abbahagyni a dohányzást & 43,1 & 2,55 \\
\hline Lefogyni néhány kilót & 43,0 & 2,8 \\
\hline Hetente legalább 3 napon komolyabb testmozgást végezni & 42,8 & 2,8 \\
\hline
\end{tabular}

4. ábra: A változással szembeni ellenállást mérő skála értékeinek megoszlása

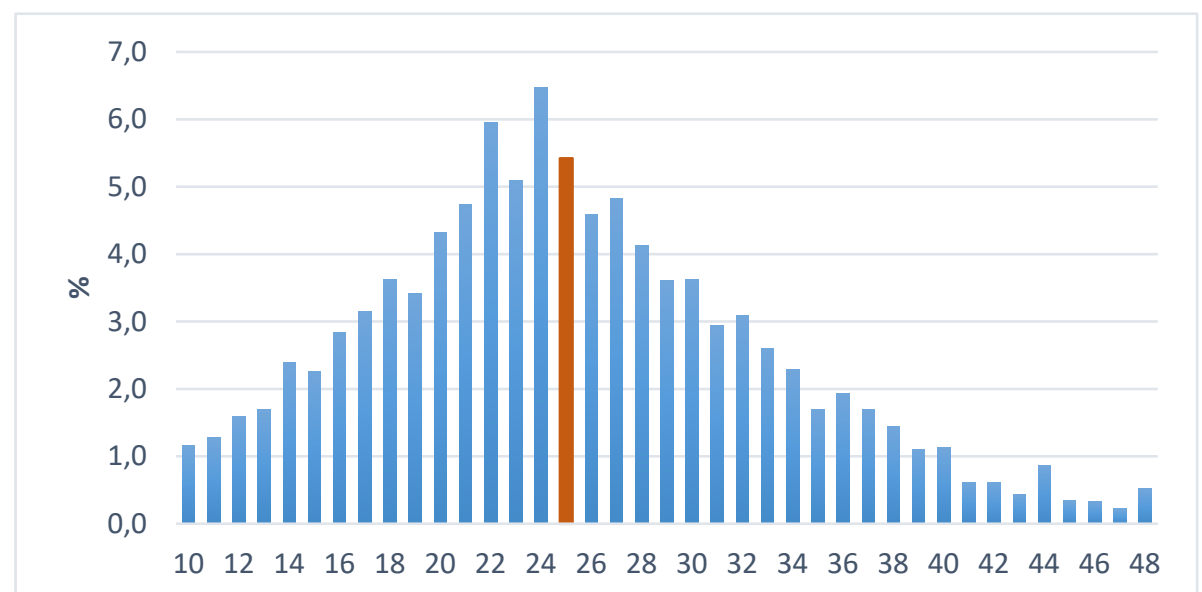

A pszichés képességeknek a viselkedésváltoztatással kapcsolatban kiemelten fontos összetevője a változáshoz való viszony. A változással szembeni ellenállás felmérésre használt 12 kérdés alapján a pontszámok a 4. ábrán látható módon oszlanak meg a felnőttek körében. A pontszám képzése az 1-től 5-ig adott válaszok összeadásával került kiszámításra, ki- véve a 4. és 10. állítás esetében, mert azok pontszáma kivonásra került az ellentétes megfogalmazás miatt. A nagyobb érték a változással szembeni nagyobb ellenállást jelzi. A minimum pontszám 10, amely a lakosok 0,5\%-ára volt jellemző, tehát ők voltak leginkább nyitottak a változásra, míg a maximum elérhető 48 pont a lakosok 1,2\%-ára volt jel-

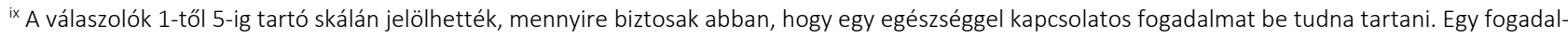
mat biztosan betartónak számítottak azok, akik a skálán 4-est vagy 5-öst választottak.
} 
lemző, ők azok, akik a legkevésbé készek a változásra. A magyar lakosok fele 25 vagy annál kevesebb pontot ért el, az átlagos pontszám 25,3.

$\mathrm{Az}$ énhatékonyság mértékének meghatározásához használt 7 kérdésre 1-től 5-ig adható válaszok alapján a magyar lakosok pontszámainak eloszlása az 5. ábra található. Minél magasabb a pontszám, annál nagyobb az énhatékonyság mértéke. A magyar felnőtt lakosság felét 27 vagy annál nagyobb pontszám jellemzi, az átlagos pontszám 26,3. Mivel az ábrán látható kiugró értékek azt jelenthetik, hogy többen valamennyi kérdésre ugyanazt a választ adták (pl. mindegyikre 5-öst), ezért célszerúnek látszik bemutatni tételenként a válaszok átlagait is. [10. táblázat]

5. ábra: Az énhatékonyság mértékének megoszlása

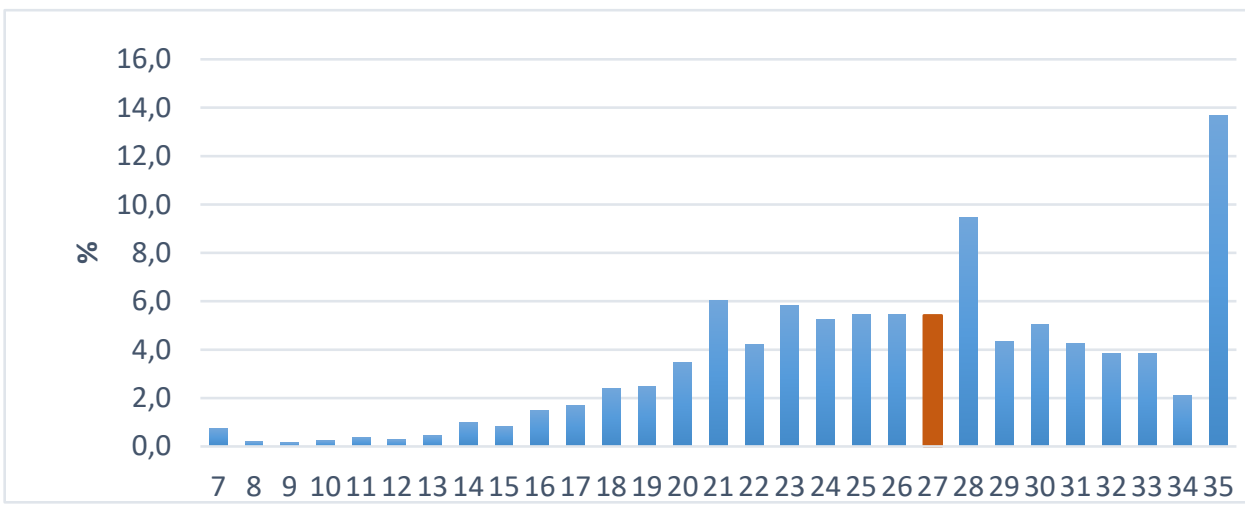

10. táblázat: Énhatékonyságra vonatkozó kérdések válaszainak átlaga

\begin{tabular}{|l|l|}
\hline \multicolumn{1}{|c|}{\begin{tabular}{|l} 
Énhatékonyságra vonatkozó állítások \\
\hline Ha akadályokkal szembesülök, megtalálom az útját-módját annak, hogy leküzdjem őket.
\end{tabular}} & 3,9 \\
\hline A nehéz problémák megoldása is sikerül, ha nagyon sokat foglalkozom velük. & 3,8 \\
\hline Váratlan helyzetben is megállom a helyem. & 3,8 \\
\hline Ha problémákkal szembesülök, saját erőmből megoldom azokat. & 3,7 \\
\hline Nem jelent problémát számomra, hogy megvalósítsam elképzeléseimet, céljaimat. & 3,6 \\
\hline Nehéz helyzetben is nyugodt maradok, mert bízom magamban. & 3,6 \\
\hline Ha új dologgal szembesülök, tudom, hogyan kezdjek a megoldáshoz. & 3,6 \\
\hline
\end{tabular}

\section{MOTIVÁLTSÁG}

Az egészség több aspektusból is fontos lehet az egyén számára. A magyar felnőtteknek legnagyobb arányban azért fontos az egészség, hogy ne fájjon semmije, ne szenvedjen betegségtől, és legkevésbé azért fontos, hogy jól nézzen ki és vonzóbb legyen. [11. táblázat]

A felnőtt lakosság fele gondol csak úgy a testmozgásra, mint kikapcsolódás, a másik fele fárasztónak ítéli meg, inkább a passzív pihenést részesítené előnyben. Ha betegségről van szó, a felnőttek fele először otthon próbálja meg kikúrálni magát, és ha nem sikerül, csak akkor megy orvoshoz, azonban a gyógyszerszedést csupán az egytizedük alapozza a barátok és ismerősek ajánlására. Az egészséges ételek a felnőtt lakosság egyötödének nem ízlenek, és egyharmadukat csak az érdekli, hogy annyit ehessen, amennyivel jóllakik. A passzív dohányzást kedvezően megítélők aránya nagyon alacsony a magyar felnőttek körében és kicsivel több, mint felük úgy ítéli meg, hogy az alkoholfogyasztást a társas környezet nagyban befolyásolja. [12. táblázat] 
11. táblázat: Az egészség fontosságára vonatkozó válaszok megoszlása és a válaszok átlaga

\begin{tabular}{|c|c|c|}
\hline Azért fontos az egészség, mert... & $\begin{array}{l}\text { Azok aránya, akiknek } \\
\text { fontos }^{x} \\
(\%)\end{array}$ & Válaszok átlaga \\
\hline jól érzi magát, nem fáj semmije, nem szenved valamilyen betegségtől & 88,8 & 4,6 \\
\hline nem kell sok időt az orvosnál töltenie & 87,9 & 4,5 \\
\hline nem kell orvosra, gyógyszerre költenie & 87,8 & 4,5 \\
\hline jobban tud gondoskodni arról, akinek szüksége van rá & 86,9 & 4,5 \\
\hline jobban el tudja látni magát, könnyebben tudja a dolgait intézni & 86,8 & 4,5 \\
\hline több időt tud együtt tölteni azokkal, akik fontosak számára & 85,2 & 4,5 \\
\hline olyasmivel tud foglalkozni, ami kikapcsolja, felüdíti, szórakoztatja, feltölti energiával & 84,2 & 4,4 \\
\hline jobban tud dolgozni és pénzt keresni & 83,0 & 4,4 \\
\hline hosszabb ideig élhet & 81,3 & 4,4 \\
\hline több helyre eljuthat, több dologban részt vehet & 79,4 & 4,3 \\
\hline többet tud másokon segíteni & 78,2 & 4,3 \\
\hline jobban néz ki, vonzóbb & 76,0 & 4,2 \\
\hline
\end{tabular}

\section{2. táblázat: Egyes egészségmagatartásra vonatkozó állitásokkal való egyetértés aránya és a válaszok átlaga}

\begin{tabular}{|c|c|c|}
\hline Egészségmagatartásra vonatkozó állitások & $\begin{array}{l}\text { Azok aránya, akik } \\
\text { egyet értenek } \\
(\%)\end{array}$ & Válaszok átlaga \\
\hline $\begin{array}{l}\text { Dohányozhat, aki akar, de ahhoz nincs joga, hogy másokat a füstje belélegzésére } \\
\text { kényszerítsen. }\end{array}$ & 81,1 & 4,3 \\
\hline A testedzés hozzásegít, hogy az ember jobban nézzen ki. & 68,4 & 3,9 \\
\hline Sokan a társaság miatt isznak. & 56,2 & 3,6 \\
\hline A testedzés, a sport segít kikapcsolódni, a feszültséget levezetni. & 54,4 & 3,5 \\
\hline $\begin{array}{l}\text { Ha megbetegszem, akkor először megpróbálom magam kikúrálni, és csak ha nem si- } \\
\text { kerül, akkor megyek orvoshoz. }\end{array}$ & 54,2 & 3,6 \\
\hline A testedzés számomra fárasztó, én inkább pihenni szeretek a szabadidőmben. & 43,1 & 3,1 \\
\hline Amikor eszem, engem főként az érdekel, hogy annyit ehessek, amennyivel jól lakom. & 39,6 & 3,1 \\
\hline Az egészségesnek tartott ételek általában nekem nem ízlenek. & 21,8 & 2,4 \\
\hline $\begin{array}{l}\text { Én csak olyan gyógyszert szedek, amiket ismerőseim a saját tapasztalataik alapján } \\
\text { ajánlanak. }\end{array}$ & 13,5 & 2,1 \\
\hline $\begin{array}{l}\text { Nem fontos, hogy a dohányzás káros az egészségre és a környezetben élők egészsé- } \\
\text { gére, ha örömet okoz. }\end{array}$ & 13,2 & 1,9 \\
\hline
\end{tabular}

\footnotetext{
× Az egészség fontosságát 1-től 5-ig tartó skálán jelölhették meg a válaszadók. Fontosnak tekintettük egy indoklást azoknál, akik a skálán 4-est vagy 5öst választottak.

${ }^{x i}$ Az egészségmagatartással kapcsolatos állítással való egyetértés erősségét a válaszolók 1-től 5-ig tartó skálán jelölhették. Egyetértőnek számítottak azok, akik a skálán 4-est vagy 5-öst választottak.
} 
Egy 10 kérdésből álló skála szolgált az élménykeresési attitűd felmérésére. ${ }^{\text {xii }}$ A kérdésekre 1-től 5-ig adható válaszok összege mutatja az élménykeresési attitűdnek a magyar felnőttekre jellemző, 6. ábrán látható megoszlását. A magasabb pontszám kifejezettebb élménykeresési attitűdöt jelez, az elérhető legkisebb pontszám 10, a legnagyobb 50. A magyar lakosok felét 17 vagy annál kisebb pontszám jellemzi, az átlagosan elért pontszám 19,6.

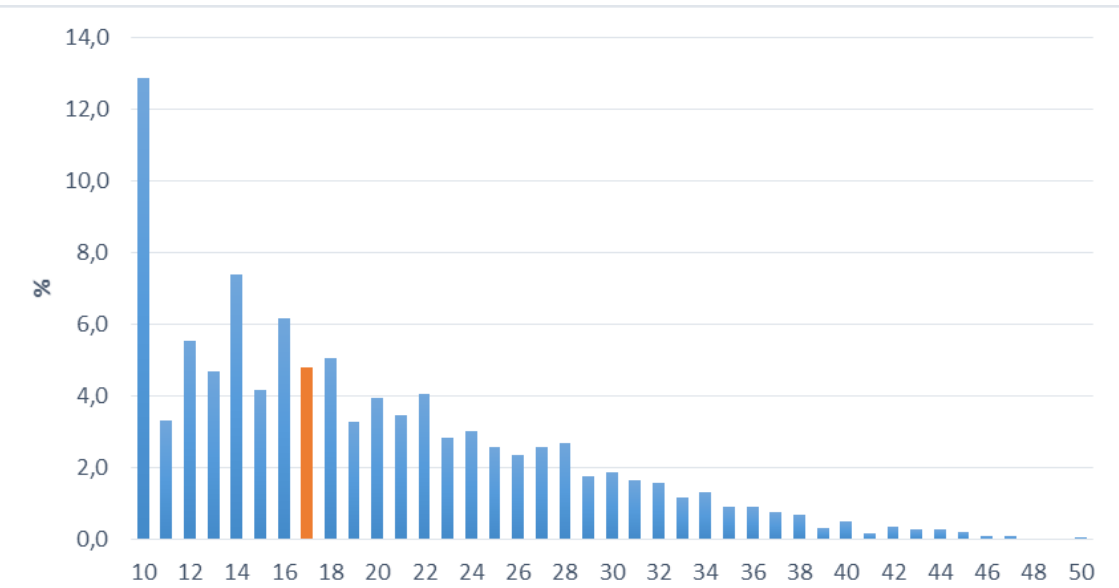

13. táblázat: Élménykeresés mértékére vonatkozó kérdésekre adott válaszok átlaga

\begin{tabular}{|c|c|}
\hline Élménykeresésre vonatkozó állítások & Válaszok átlaga \\
\hline Szeretnék felfedezni idegen helyeket. & 3,3 \\
\hline Jobban szeretem azokat a barátokat, akik meglepetést okoznak nekem. & 2,4 \\
\hline Nyugtalan leszek, ha túl sok időt töltök otthon. & 2,0 \\
\hline Szeretek kockáztatni. & 1,8 \\
\hline Szeretném kipróbálni a kötélugrást (bungee jumping) vagy a vadvízi evezést. & 1,8 \\
\hline Szeretnék új és izgalmas élményeket megtapasztalni, még akkor is, ha ezek révén törvényt szegek. & 1,6 \\
\hline Szeretem a vad bulikat. & 1,5 \\
\hline A szórakozás kedvéért megéri, hogy bajba kerüljek. & 1,3 \\
\hline
\end{tabular}

A helytelennek tartott magatartás megváltoztatásának elkerülését legtöbben különféle kifogásokkal indokolják. A magyar felnőtt lakosság leggyakrabban felhozott kifogása az, hogy nagyon nehezen szánja rá magát, a második leggyakoribb kifogás szerint pe- dig az illető csak nem akar változtatni, vagyis hiányzik az elhatározás, a motiváció. A családi és baráti ellenzés, mint hátráltató társas környezet a felnőttek alig 4\%-ára jellemző. [14. táblázat]

xii A 10 tételes szenzoros élménykeresés kérdőívre nem volt található magyar, standard értékelési eljárás, így a szerzők egyszerű leíró statisztikát alkalmaztak. 
14. táblázat: A helytelennek tartott magatartás megváltoztatásának elkerülésére vonatkozó kifogások aránya és a válaszok átlaga

\begin{tabular}{|c|c|c|}
\hline Azért nem változtatok azon, ahogy élek, mert... & $\begin{array}{c}\text { Azok aránya, akikre } \\
\text { igaz } \\
(\%)\end{array}$ & Válaszok átlaga \\
\hline nagyon nehéz rászánnom magam. & 34,5 & 2,8 \\
\hline egyszerúen csak nem akarok. & 32,6 & 2,7 \\
\hline nincs elegendő pénzem hozzá. & 27,1 & 2,5 \\
\hline már túl öreg vagyok én ahhoz. & 21,8 & 2,2 \\
\hline nem érek rá ilyesmire. & 17,1 & 2,2 \\
\hline már megpróbáltam, de nem sikerült. & 16,9 & 2,2 \\
\hline igazából nem rajtam múlik. & 12,8 & 2,0 \\
\hline akkor sokkal idegesebb, feszültebb lennék. & 12,7 & 2,0 \\
\hline túl sokat kellene gyalogolnom vagy utaznom miatta. & 11,4 & 1,9 \\
\hline jó nekem így is, úgysem szeretnék sokáig élni. & 8,5 & 1,7 \\
\hline ellenzi a családom, vagy, mert a barátaim, az ismerőseim megszólnának érte. & 3,7 & 1,5 \\
\hline
\end{tabular}

$\mathrm{Az}$, hogy valaki hogyan ítéli meg a saját életét, mennyire elégedett azzal, az a viselkedésváltoztatás szempontjából fontos motivációs tényezőnek tekinthető. A felnőtt lakosság életével való elégedettségét a 7. ábra mutatja. A válaszoló egy 11 fokú skála (0-tól 10-ig összesen 11 válaszlehetőség) jelölte meg, hogy milyennek tartja életét. A magyar felnőttek átlagosan a 7. fokot választották.
A felmérésben adott válaszok alapján a felnőtt lakosság több mint 90\%-ának az a legfontosabb életcélja, hogy elkerüljék a betegségek. [15. táblázat] Hasonló arányban, a második legfontosabb cél, hogy legyenek olyanok az életükben, akik szeretik, és akiket szerethetnek. A választható kilenc életcél közül utolsóként, csak minden 8. felnőtt számára fontos az, hogy híres legyen.

\section{7. ábra: Élettel való elégedettség mértékének megoszlása}

a lehető legjobb élet

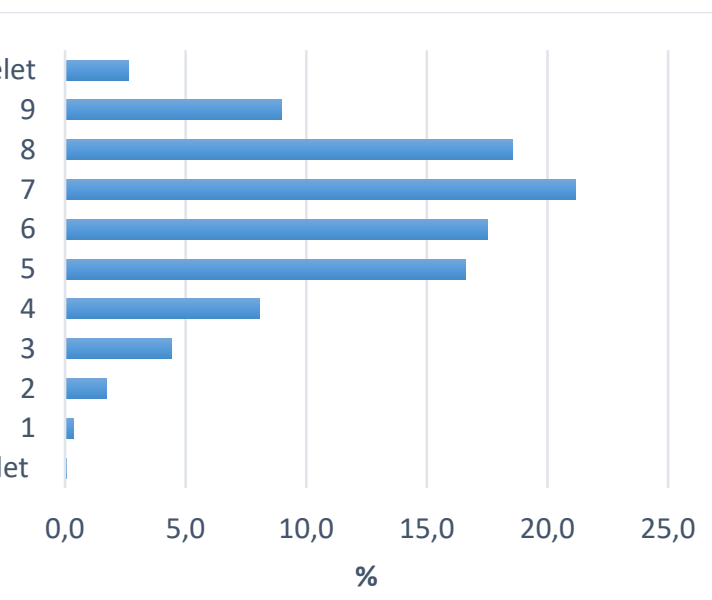

a lehető legrosszabb élet

\footnotetext{
xiii A helytelennek tartott magatartás megváltoztatásának elkerülésére vonatkozó kifogást 1-től 5-ig tartó skálán jelölhették magukra vonatkozóan jellemzőnek. Egy kifogás igaznak számított azoknál, akik a skálán 4-est vagy 5-öst választottak.
} 
15. táblázat: Egyes életcélokat fontosnak tartók aránya és a válaszok átlaga

\begin{tabular}{|l|c|c|}
\hline Mennyire fontos az Ön számára, hogy elérje ezeket a célokat? & $\begin{array}{c}\text { Azok aránya, aki fon- } \\
\text { tosnak tartja xiv } \\
(\%)\end{array}$ & \begin{tabular}{c} 
Válaszok átlaga \\
\hline elkerüljék a betegségek
\end{tabular} \\
\hline legyenek olyanok, akik szeretik, és akiket Ön szerethet & 87,6 & 4,6 \\
\hline ismerje és elfogadja önmagát & 78,4 & 4,2 \\
\hline sok ember tisztelje & 61,1 & 3,7 \\
\hline hozzájáruljon, hogy a világ jobb legyen & 58,1 & 3,7 \\
\hline új dolgokat tanuljon & 52,5 & 3,4 \\
\hline gazdag legyen & 44,4 & 3,3 \\
\hline vonzónak tartsák & 43,0 & 3,2 \\
\hline híres legyen & 12,6 & 2,0 \\
\hline
\end{tabular}

\section{KÖRNYEZET}

A magyar felnőttek $12 \%$-a érzi igaznak vagy teljes mértékben igaznak magára azt az állítást, hogy azért nem változtat helytelennek tartott magatartásán, mert túl sokat kellene gyalogolnia, vagy utaznia miatta. A felnőtt lakosok 27\%-a pedig a változtatás akadályaként a nem elegendő anyagi forrást azonosította.

A felnőtt lakosság kétharmada szerint társas környezetére jellemző, hogy természetesnek tartják a sok zöldség- és gyümölcsfogyasztást, és hogy a testi tünetekkel járó betegségekkel szakemberhez kell fordulni. [16. táblázat] A testmozgás azonban már nem élvez ilyen magas arányú támogatást, csupán a felnőttek egyharmadának környezetében elvárás a rendszeres sport.

A társas támogatottság egyik jellemzőjének tekinthető a barátnak tartott személyek száma. A felnőtt magyar lakosoknak legnagyobb arányban legalább 3-5 barátja van, és a felnőttek csupán 3\%-ára jellemző, hogy egyetlen barátja sincs. [8. ábra]

A társas támogatottságra vonatkozó további kérdések alapján megállapítható, hogy a felnőttek közel 80\%-a úgy véli, a környezetük megfelelően törődik velük, és $61 \%$-uk biztos abban, hogy szükség esetén könnyen kapna segítséget a szomszédjától.

16. táblázat: A társas környezet elvárását jellemzőnek tartók aránya és a válaszok átlaga

\begin{tabular}{|c|c|c|}
\hline Önhöz közel álló személyek... & $\begin{array}{l}\text { Azok aránya, akiknek jel- } \\
\text { lemző a környezetére } \\
(\%)^{\mathrm{xv}}\end{array}$ & Válaszok átlaga \\
\hline természetesnek tartják, hogy sok zöldséget, gyümölcsöt kell enni. & 69,1 & 3,9 \\
\hline körében az az elvárás, hogy mindenki sokat mozogjon, sportoljon. & 33,2 & 2,9 \\
\hline körében elfogadott, ha valaki többet iszik a kelleténél. & 14,4 & 2,1 \\
\hline körében elfogadott, ha valaki dohányzik. & 28,7 & 2,7 \\
\hline $\begin{array}{l}\text { körében az a természetes, hogy a testi tünetekkel járó betegséggel minél gyorsab- } \\
\text { ban szakemberhez kell fordulni. }\end{array}$ & 69,1 & 3,9 \\
\hline $\begin{array}{l}\text { körében az a természetes, hogy lelki problémákkal minél gyorsabban szakember- } \\
\text { hez kell fordulni. }\end{array}$ & 53,9 & 3,6 \\
\hline
\end{tabular}

\footnotetext{
xiv A választható életcélok fontosságát 1-től 5-ig tartó skálán jelölhették meg a válaszadók. Fontosnak tekintettük egy életcélt azoknál, akik a skálán 4est vagy 5-öst választottak.

${ }^{x v}$ Az állitásokkal való egyetértés mértékét 1-től 5-ig tartó skálán jelölhették meg a válaszadók. Jellemzőnek számított, ha a válaszoló a skálán 4-est vagy 5-öst választotta.
} 
8. ábra: A barátoknak tartott személyek számának megoszlása

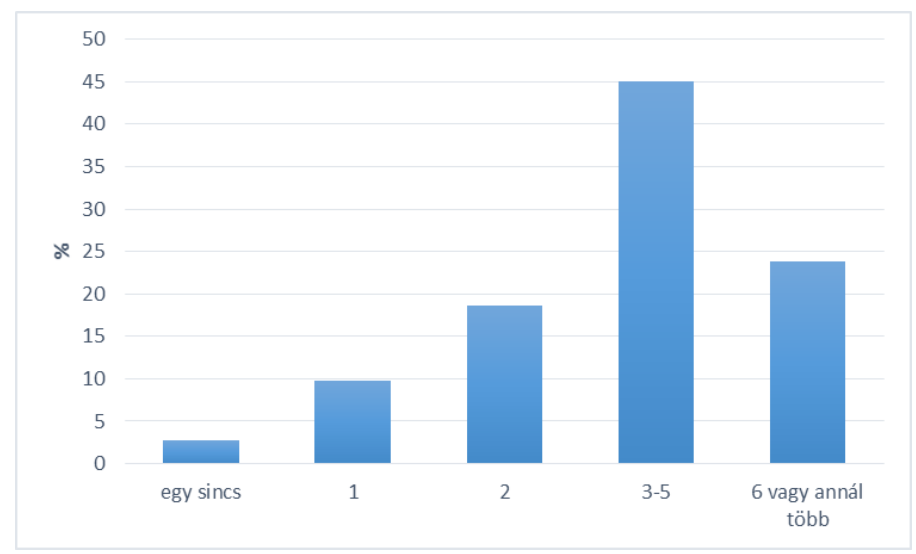

\section{ÖSSZEGZÉS}

Az EKF COM-B modell alapján összeállított kérdésekre kapott, a közleményben ismertetett válaszok lehetőséget nyújtanak az egészségfejlesztés különböző területein tevékenykedő szakemberek számára, hogy a magyar felnőtt lakosság fizikai-pszichikai képességeire, motivációira, társas illetve fizikai környezetére és viselkedésére vonatkozó eredményeket saját munkájukhoz hasznosítsák. A közleményben bemutatott egyszerű, leíró statisztikai eredmények nem feltétlenül illeszkednek a szakemberek különféle speciális kérdésfelvetéséhez, de mivel a vizsgálók hozzáférhetővé tették a felmérés adatbázisát, a válaszok további, részletesebb elemzései elvégezhetők a letöltött adatokon. ${ }^{32}$ Ezáltal lehetőség nyilik az adott kérdésfelvetéshez illeszkedő különböző ismérvek, mint életkor, nem, iskolázottság szerinti tetszőleges bontásokra, mélyebb összefüggések értékelésére.

A válaszok elemzésekor, az eredmények értelmezésekor feltétlenül figyelembe kell venni, hogy az EKFben alkalmazott kérdőív egészében nem tekinthető validáltnak, hiszen az jó néhány saját fejlesztésű kérdésből vagy a nemzetközi szakirodalomból átvett skálából vagy annak részletéből lett összeállítva. Az EKF kérdőívének kifejlesztésekor ugyanis a cél a COM-B modellnek megfelelő minél több információ összegyújtése volt, ezért a vizsgálatnak ebben az exploratív szakaszában a kutatók a „próba-szerencse" megközelítéssel minél több kérdést alkalmaztak az egyének egészségstílus csoportokba sorolásához. A vizsgálat következő, konfirmatív fázisában a kérdések közül már ki lehet választani azokat, amelyek valóban fontosak voltak az egyének egészségstílusokba csoportosításához. Az EKF kérdőívével nyert adatok tehát korlátozottan alkalmasak más célú elemzések, vagy más felmérések eredményeivel történő összevetésre.

A bemutatott leíró statisztikai eredmények értelmezésekor feltétlenül figyelembe kell venni, hogy egyegy fentiekben ismertetett eredmény önmagában korlátozottan felhasználható, inkább csak tájékozódásra alkalmas. A szakemberek számára fontos hangsúlyozni, hogy az adatok alapján egy adott társadalmi csoport esetében kizárólag a négy tényezőt (képesség, motiváció, környezet, viselkedés) együttesen, összefüggéseiben kezelő, az un. egészségstílusok ismeretében lehet hatásos beavatkozásokat tervezni és megvalósítani. A felmérés eredményei alapján képzett egészségstílusok bemutatására egy következő, angol nyelvű közleményben kerül sor, mivel a viselkedésváltoztatás területén innovatívnak számító megközelítés nemzetközi érdeklődésre tarthat számot.

\footnotetext{
${ }^{1}$ Balku E, Berki J, Csizmadia P, Csohán Á, Horváth G, Kurcz A, Melles M, Bakacs M, Boros J, Györke J, Pásztorné Stokker E, Szabó KZs. Egészségjelentés2015. Varsányi P, Vitrai J (szerk). Nemzeti Egészségfejlesztés Intézet, Budapest, 2015.

${ }^{2}$ Morris J, Marzano M, Dandy N, O’Brien L. Theories and models of behaviour and behaviour change. For Sustain Behav Behav Chang Theor. 2012:1-27.
} 
${ }^{3}$ Michie S, Johnston M, Abraham C, Lawton R, Parker D, Walker A. Making psychological theory useful for implementing evidence based practice: a consensus approach. Qual Saf Health Care. 2005;14(1):26-33.

doi:10.1136/qshc.2004.011155.

${ }^{4}$ Michie S, van Stralen MM, West R. The behaviour change wheel: a new method for characterising and designing behaviour change interventions. Implement Sci. 2011;6:42. doi:10.1186/1748-5908-6-42.

${ }^{5}$ Michie S, Atkins L, West R. The Behaviour Change Wheel. A Guide to Designing Interventions. http://www.behaviourchangewheel.com/ (Elérve: 2016.07.14.)

${ }^{6}$ Kimmel Z, Vitrai J. Mennyire változtatható jogszabályokkal az egészségmagatartás? Elegendőek-e a szabályozások az egészségmagatartás megváltoztatásához? II. rész. Egeszsegtudomany. 2015;(3):71-78.

${ }^{7}$ Eurostat. European Health Interview Survey (EHIS wave 2).; 2013.

http://ec.europa.eu/eurostat/documents/3859598/5926729/KS-RA-13-018-EN.PDF/26c7ea80-01d8-420e-bdc6e9d5f6578e7c (Elérve: 2016.07.14.)

${ }^{8}$ World Health Organization. Global Physical Activity Questionnaire ( GPAQ ). 2013:1-3.

http://www.who.int/chp/steps/GPAQ/en/ (Elérve: 2016.07.14.)

${ }_{9}^{9}$ World Health Organization. Global Adult Tobacco Survey (GATS). 2007.

http://www.who.int/tobacco/surveillance/survey/gats/en/ (Elérve: 2016.07.14.)

${ }^{10}$ Utility C, Properties P. AUDIT-C Questionnaire. Intern Med. 2003;163(April):2-3.

${ }^{11}$ Lenus, The Irish Health Repository. Alcohol: public knowledge, attitudes and behaviours. 2012.

http://hse.openrepository.com/hse/handle/10147/234315 (Elérve: 2016.07.14.)

12 Bush, Kristen; Kivlahan, Daniel R.; McDonell, Mary B.; Fihn, Stephan D.; Bradley KA. The AUDIT Alcohol Consumption Questions (AUDIT-C): An Effective Brief Screening Test for Problem Drinking. Arch Intern Med. 1998;158(16):17891795. doi:10.1001/archinte.158.16.1789.

${ }^{13}$ Networks C. E-Communications Household Survey. 2013; (November).

${ }^{14}$ Majerszki N. The Z Generation of the Twenty First Century. Verpelét; 2014.

http://www.norria.hu/files/1029/Peabo Media Kft Z generáció és a közösségi média.pdf (Elérve: 2016.07.14.)

${ }^{15}$ Központi Statisztikai Hivatal. Európai lakossági egészségfelmérés, 2014, Statisztikai tükör; 2015;29:1-9.

${ }^{16}$ Weber EU, Blais A-R, Betz NE. A domain-specific risk-attitude scale: Measuring risk perceptions and risk behaviors. J Behav Decis Mak. 2002;15(August):263-290. doi:10.1002/bdm.414.

17 Goldberg DP, Hillier VF. A scaled version of the General Health Questionnaire. Psychol Med. 1979;9:139-145. doi:10.1017/S0033291700021644.

${ }_{18}$ Wardle AJ, Steptoe A, Wardle J. Socioeconomic Differences in Attitudes and Beliefs about Healthy Lifestyles. Epidemiol Community Health. 2003;57(6):440-443.

${ }^{19}$ Oreg S. Resistance to change: Developing an individual differences measure. J Appl Psychol. 2003;88(4):680-693. doi:Doi 10.1037/0021-9010.88.4.680.

${ }^{20}$ Schwarzer, R., \& Jerusalem M. General Self-efficacy Scale. Meas Heal Psychol A user's portfolio Causal Control beliefs. 1995;(2008):35-37. doi:10.1037/t00393-000.

${ }^{21}$ Gosling SD, Rentfrow PJ, Swann WB. A very brief measure of the Big-Five personality domains. J Res Pers. 2003;37(6):504-528. doi:10.1016/S0092-6566(03)00046-1.

22 Semmelweis University Budapest. Hungarostudy. 2013. http://www.hungarostudy.hu/index.php/2014-04-07-17-2112/hungarostudy-2013 (Elérve: 2016.07.14.)

${ }^{23}$ Craig R, Shelton N. Health Survey for England 2007, Healthy lifestyles : knowledge, attitudes and behaviour. Köt 1. London; 2008.

${ }^{24}$ Abbott R, Macdonald D, Stubbs C, Lee A, Harper C, Davies P. Healthy Kids Queensland Survey 2006 - Full Report.; 2008. http://www.health.qld.gov.au/ph/documents/hpu/healthykidsqld2006.pdf (Elérve: 2016.07.14.)

${ }^{25}$ EU. Sport and physical activity -- Special Eurobarometer.; 2014. doi:10.2766/73002.

${ }^{26}$ European Commission. A Pan-EU Survey on Consumer Attitudes to Physical Activity, Body-weight and Health.; 1999.

${ }^{27}$ Cantril H. The pattern of human concerns. Köt Rutgers Un. New Brunswick, New Jersey, USA; 1965.

${ }^{28}$ Kasser T, Ryan RM. Further Examining the American Dream: Differential Correlates of Intrinsic and Extrinsic Goals. Personal Soc Psychol Bull. 1996;22(3):280-287. doi:10.1177/0146167296223006.

${ }^{29}$ Hoyle RH, Stephenson MT, Palmgreen P, Lorch EP, Donohew RL. Reliability and validity of a brief measure of sensation seeking. Pers Individ Dif. 2002;32(3):401-414. doi:10.1016/S0191-8869(01)00032-0.

${ }^{30}$ Eurostat. SILC. 2015. http://ec.europa.eu/eurostat/web/income-and-living-conditions/overview (Elérve: 2016.07.14.)

${ }^{31}$ Kroenke K, Spitzer RL. The PHQ-9 : A New Depression Measure. Psychiatr Ann. 2002;32(9):509-515. doi:170553651.

32 EKF szakmai anyagok. http://www.egeszseg.hu/szakmai oldalak/oldal/szakmai-anyagok/szakmai-anyagokegeszsegkommunikacios-felmeres/ (Elérve: 2016.07.14.) 